\title{
Vanadium-Catalyzed Chlorination under Molecular Oxygen
}

\author{
Toshiyuki Moriuchi, ${ }^{* a}$ Yasuhiro Fukui, Satoshi Kato, Tomomi Kajikawa, and
} Toshikazu Hirao*a,b

${ }^{a}$ Department of Applied Chemistry, Graduate School of Engineering, Osaka University, Yamada-oka, Suita, Osaka 565-0871, Japan

b JST, ACT-C, 4-1-8 Honcho, Kawaguchi, Saitama 332-0012, Japan

*Corresponding authors:

T. Moriuchi: E-mail: moriuchi@chem.eng.osaka-u.ac.jp

T. Hirao: E-mail: hirao@chem.eng.osaka-u.ac.jp 


\begin{abstract}
.
A catalytic chlorination of ketones was performed by using a vanadium catalyst in the presence of $\mathrm{Bu}_{4} \mathrm{NI}$ and $\mathrm{AlCl}_{3}$ under atmospheric molecular oxygen. This catalytic chlorination could be applied to the chlorination of alkenes to give the corresponding vic-dichlorides. $\mathrm{AlCl}_{3}$ was found to serve as both a Lewis acid and a chloride source to induce the facile chlorination. A combination of $\mathrm{Bu}_{4} \mathrm{NI}$ and $\mathrm{AlI}_{3}$ in the presence of a vanadium catalyst under atmospheric molecular oxygen induced the iodination of ketones.
\end{abstract}

Keywords: Vanadium catalyst; Chlorination; Iodination; Molecular oxygen; Lewis acid 


\section{Introduction.}

Halogenation reaction is one of the most important reactions in the field of organic synthesis, providing versatile precursors and substrates in a variety of coupling reactions. Haloperoxidases are enzymes that catalyze the oxidation of halide ions in the presence of $\mathrm{H}_{2} \mathrm{O}_{2}$ as an oxidant [1-5]. Haloperoxidases have attracted extensive interest due to their capability to halogenate a range of organic compounds. Various bromination reactions mimicking a catalytic activity of vanadium bromoperoxidase [6], which is a naturally occurring enzyme found in marine algae, have been reported [7-17]. Tungsten [18] or molybdenum [19] complexes have been also demonstrated to serve as a bromination catalyst in the presence of stoichiometric hydrogen peroxide. However, these oxidative bromination systems require a stoichiometric amount of a strong oxidant to generate the bromonium-like species. Some catalytic oxidative bromination reactions with molecular oxygen as a terminal oxidant instead of a strong oxidant have been achieved [20-24]. Recently, we have performed the combination of a vanadium catalyst, a bromide salt, and a Brønsted acid or a Lewis acid in the presence of molecular oxygen induces catalytic oxidative bromination of various arenes, alkenes, alkynes, and ketones without usage of a strong oxidant [25-27]. These findings prompted us to develop an efficient halogenation method. In this paper, we report the catalytic chlorination reaction of ketones and alkenes without need of a strong oxidant by using a vanadium catalyst in the presence of $\mathrm{Bu}_{4} \mathrm{NI}$ and $\mathrm{AlCl}_{3}$ with molecular oxygen as a terminal oxidant.

\section{Experimental}

\subsection{General materials and experimental procedures}

All reagents and solvents were purchased from commercial sources and were further

purified by the standard methods, if necessary. ${ }^{1} \mathrm{H}$ NMR spectra were recorded in $\mathrm{CDCl}_{3}$ on a 
JNM-ECS $400(400 \mathrm{MHz})$ spectrometer. Chemical shifts were determined by using of tetramethylsilane as an internal standard.

2.2. General procedure for vanadium-catalyzed chlorination under atmospheric molecular oxygen

In a $5 \mathrm{~mL}$ three-necked flask, $\mathrm{Bu}_{4} \mathrm{NI}(111 \mathrm{mg}, 0.3 \mathrm{mmol}), \mathrm{AlCl}_{3}(40 \mathrm{mg}, 0.3 \mathrm{mmol})$, and $\mathrm{VO}\left(\mathrm{O}^{i} \mathrm{Pr}\right)_{3}(15 \mu \mathrm{L}, 0.063 \mathrm{mmol})$ were placed. The flask was evacuated and backfilled with molecular oxygen. To the mixture, acetonitrile $(1 \mathrm{~mL})$ and a substrate $(0.25 \mathrm{mmol})$ were added. The mixture was stirred at $80{ }^{\circ} \mathrm{C}$ under atmospheric molecular oxygen, followed by treatment with 1:1 mixture of saturated $\mathrm{Na}_{2} \mathrm{~S}_{2} \mathrm{O}_{3}$ aqueous solution and saturated $\mathrm{NaHCO}_{3}$ aqueous solution, and extraction with ether. The organic layer was dried over $\mathrm{MgSO}_{4}$, filtered, and evaporated. 1,3,5-Trimethoxybenzene or 1,2,4,5-tetramethylbenzene was added as an internal standard, and ${ }^{1} \mathrm{H}$ NMR analysis was performed to determine a NMR yield. Spectral data of the products were identical with those of commercially available and authentic samples.

\subsection{General procedure for vanadium-catalyzed iodination under atmospheric molecular oxygen}

In a $5 \mathrm{~mL}$ three-necked flask, $\mathrm{Bu}_{4} \mathrm{NI}(111 \mathrm{mg}, 0.3 \mathrm{mmol}), \mathrm{AlI}_{3}(122 \mathrm{mg}, 0.3 \mathrm{mmol})$, and $\mathrm{NH}_{4} \mathrm{VO}_{3}(2.9 \mathrm{mg}, 0.025 \mathrm{mmol})$ were placed. The flask was evacuated and backfilled with molecular oxygen. To the mixture, acetonitrile $(1 \mathrm{~mL})$ and a substrate $(0.25 \mathrm{mmol})$ were added. The mixture was stirred at $80{ }^{\circ} \mathrm{C}$ under atmospheric molecular oxygen, followed by treatment with 1:1 mixture of saturated $\mathrm{Na}_{2} \mathrm{~S}_{2} \mathrm{O}_{3}$ aqueous solution and saturated $\mathrm{NaHCO}_{3}$ aqueous solution, and extraction with ether. The organic layer was dried over $\mathrm{MgSO}_{4}$, filtered, and evaporated. 1,2,4,5-tetramethylbenzene was added as an internal standard, and ${ }^{1} \mathrm{H}$ NMR analysis was performed to determine a NMR yield. Spectral data of the products were identical with those of commercially available and authentic samples. 


\subsection{Gram-scale reaction of propiophenone}

In a $50 \mathrm{~mL}$ three-necked flask, $\mathrm{Bu}_{4} \mathrm{NI}(4.43 \mathrm{~g}, 12 \mathrm{mmol}), \mathrm{AlCl}_{3}(1.60 \mathrm{~g}, 12 \mathrm{mmol})$, and $\mathrm{VO}\left(\mathrm{O}^{i} \mathrm{Pr}\right)_{3}(472 \mu \mathrm{L}, 2.0 \mathrm{mmol})$ were placed. The flask was evacuated and backfilled with molecular oxygen. To the mixture, acetonitrile $(30 \mathrm{~mL})$ and propiophenone $(1.33 \mathrm{~mL}, 10 \mathrm{mmol})$ were added. The mixture was stirred at $80{ }^{\circ} \mathrm{C}$ under atmospheric molecular oxygen for $24 \mathrm{~h}$, followed by treatment with 1:1 mixture of saturated $\mathrm{Na}_{2} \mathrm{~S}_{2} \mathrm{O}_{3}$ aqueous solution and saturated $\mathrm{NaHCO}_{3}$ aqueous solution, and extraction with ether. The organic layer was dried over $\mathrm{MgSO}_{4}$, filtered, and evaporated. The residue was chromatographed on a silica gel column eluting with hexane and dichloromethane to give $1.32 \mathrm{~g}$ (78\% yield) of 2-chloro-1-phenylpropan-1-one.

\section{Results and Discussion.}

$\alpha$-Halocarbonyl compounds are regarded as important precursors for various transformations employed in organic and pharmaceutical syntheses. The chlorination reaction of propiophenone in the presence of $10 \mathrm{~mol} \%$ of $\mathrm{NH}_{4} \mathrm{VO}_{3}, 120 \mathrm{~mol} \%$ of $\mathrm{Bu}_{4} \mathrm{NI}$, and $120 \mathrm{~mol} \%$ of $\mathrm{AlCl}_{3}$ as a Lewis acid in $\mathrm{MeCN}$ at $80{ }^{\circ} \mathrm{C}$ for $24 \mathrm{~h}$ under atmospheric molecular oxygen was performed (Table 1, entry 1). The chlorination reaction proceeded well to afford the $\alpha$ chlorocarbonyl compound $\mathbf{2 a}$ in $60 \%$ yield. No chlorination product was obtained in the absence of $\mathrm{NH}_{4} \mathrm{VO}_{3}$ (entry 2). This catalytic chlorination reaction was not effectively performed under argon atmosphere (entry 3). The chlorination reaction in other solvents, such as dimethoxyethane (DME), cyclopentyl methyl ether (CPME), and ether resulted in a slightly decreased yield (entries 4-6). The use of $200 \mathrm{~mol} \%$ of $\mathrm{Bu}_{4} \mathrm{NI}$, and $200 \mathrm{~mol} \%$ of $\mathrm{AlCl}_{3}$ did not show a drastically enhanced yield (entry 7). With an increased amount (20 mol\%) of $\mathrm{NH}_{4} \mathrm{VO}_{3}$, the $\alpha$-chlorocarbonyl 
derivative 2a was produced in a good yield (entry 8). Highly active catalysis was observed with $\mathrm{VO}\left(\mathrm{O}^{i} \mathrm{Pr}\right)_{3}$ (entry 9) although $\mathrm{VO}(\mathrm{acac})_{2}$ and $\mathrm{VOCl}_{3}$ exhibited a similar catalytic activity (entries 10-11). The $\alpha$-chlorocarbonyl compound 2a was obtained quantitatively by extending the reaction time (entry 12 ).

\section{[Insert Table 1]}

The effect of a halide source and aluminium halide in catalytic halogenation of propiophenone by using $\mathrm{NH}_{4} \mathrm{VO}_{3}$ as a catalyst was examined (Table 2). KI was not effective in the chlorination (entry 2). The combination of $\mathrm{Bu}_{4} \mathrm{NCl}$ and $\mathrm{AlI}_{3}$ induced the formation of the $\alpha$ chlorination product $\mathbf{2 a}$ in $58 \%$ yield together with the $\alpha$-iodination one 3a in $16 \%$ yield (entry 3 ). The use of $\mathrm{Bu}_{4} \mathrm{NCl}$ and $\mathrm{AlCl}_{3}$ showed no promising results (entry 4). With $\mathrm{Bu}_{4} \mathrm{NI}$ and $\mathrm{AlI}_{3}$, the iodination reaction proceeded to give $\mathbf{3 a}$ in $33 \%$ yield (entry 5). Lewis acidity of $\mathrm{AlX}_{3}$ and oxidation potentials of halide ions are considered to be key factors in this vanadium-catalyzed chlorination. Extending the reaction time led to a $16 \%$ increase in yield (entry 6).

[Insert Table 2]

The chlorination reaction of 4'-methoxyacetophenone in the presence of $20 \mathrm{~mol} \%$ of $\mathrm{NH}_{4} \mathrm{VO}_{3}, 120 \mathrm{~mol} \%$ of $\mathrm{Bu}_{4} \mathrm{NI}$, and $120 \mathrm{~mol} \%$ of $\mathrm{AlCl}_{3}$ in $\mathrm{MeCN}$ at $80{ }^{\circ} \mathrm{C}$ for $36 \mathrm{~h}$ under atmospheric molecular oxygen afforded the $\alpha$-chlorocarbonyl compound $\mathbf{2 b}$ in $49 \%$ yield as a major product with the dichlorination product $\mathbf{2 b b}$ in $3 \%$ yield (Table 3, entry 1). Longer reaction time led to a slightly increased yield (entry 2). In the case of 4'-chloroacetophenone, $\alpha$ chlorination product $2 \mathrm{c}$ was obtained in 55\% yield (entry 3). $\beta$-Keto esters such as ethyl 
benzoylacetate underwent the chlorination to give the monochlorinated product $\mathbf{2 d}$ with a trace amount of monochlorinated product 3d (entry 4).

[Insert Table 3]

A catalytic chlorination of ketones by using cat. $\mathrm{VO}\left(\mathrm{O}^{i} \mathrm{Pr}\right)_{3} / \mathrm{Bu}_{4} \mathrm{NI} / \mathrm{AlCl}_{3} / \mathrm{O}_{2}$ system was examined (Table 4). The chlorination reaction of 4'-methoxyacetophenone proceeded to afford the $\alpha$-chlorination product $\mathbf{2 b}$ in a moderate yield and the dichlorination product $\mathbf{2 b b}$ in $13 \%$ yield with a trace amount of the $\alpha$-iodination product $\mathbf{3 b}$ (entry 1$). \mathrm{VO}\left(\mathrm{O}^{i} \mathrm{Pr}\right)_{3}$ showed higher efficiency than $\mathrm{NH}_{4} \mathrm{VO}_{3}$. 4'-Chloroacetophenone was chlorinated to give the monochlorinated product $2 \mathrm{c}$ in $66 \%$ yield and the dichlorination product $2 \mathrm{cc}$ in $13 \%$ yield together with a small amount of the $\alpha$-iodinated product 3c (entry 2). Starting from acetophenone, the $\alpha$-chlorinated product $2 \mathrm{e}$ was obtained in $84 \%$ yield with the dichlorinated product $2 \mathrm{ee}$ in $12 \%$ yield and a small amount of the $\alpha$-iodinated product 3e (entry 3 ). This catalytic chlorination could be applied to the chlorination of alkenes (Table 5). 1-Decene underwent the selective vic-chlorination to afford 1,2-dichlorodecane (5a) in 72\% yield (entry 1). Catalytic chlorination of 5-hexene-1-ol proceeded smoothly to give the dichlorinated product $\mathbf{5 b}$ in $78 \%$ yield with the hydroxy group intact (entry 2). Allylbenzene was converted into the dichloride in $87 \%$ yield (entry 3 ).

[Insert Table 4]

[Insert Table 5]

It is noteworthy to mention that a gram-scale reaction underwent successfully to give the expected chlorinated product in a high yield, as exemplified by the $\alpha$-chlorination of 
propiophenone in $78 \%$ isolated yield as shown in Scheme 1. Starting from $\alpha$-iodo ketone $\mathbf{3 a}, \alpha$ chloro ketone 2a was obtained as a sole product selectively (Scheme 2). Thus, the key intermediate for the chlorination is proposed to be $\alpha$-iodo ketone $\mathbf{3 a}$, which is considered to be generated by the oxidation of an iodide ion via oxygen-atom transfer of an oxovanadium species activated by a Lewis acid [26-27].

[Insert Scheme 1]

[Insert Scheme 2]

\section{Conclusions}

The catalytic chlorination reaction of ketones without use of a strong oxidant was achieved by using a commercially available inexpensive ligand-free vanadium catalyst in the presence of $\mathrm{Bu}_{4} \mathrm{NI}$ and $\mathrm{AlCl}_{3}$ with molecular oxygen as a terminal oxidant, in which $\mathrm{AlCl}_{3}$ was found to serve as both as a Lewis acid and a chloride source to induce the facile chlorination. This catalytic system was also demonstrated to be capable of inducing the catalytic chlorination of alkenes to afford the corresponding vic-dichlorides. The combination of $\mathrm{Bu}_{4} \mathrm{NI}$ and $\mathrm{AlI}_{3}$ in the presence of a vanadium catalyst under atmospheric molecular oxygen was found to induce the iodination of ketones. Studies on the reaction mechanism and synthetic versatility, and application of this practical method to other reactions are now in progress.

\section{Acknowledgment.}


This work was supported partly by a Grant-in-Aid for Scientific Research ACT-C program of the Japan Science and Technology Agency (JST). Thanks are due to the Analytical Center, Graduate School of Engineering, Osaka University. The donation of $\mathrm{VO}\left(\mathrm{O}^{i} \mathrm{Pr}\right)_{3}$ from the Nichia corporation is also acknowledged. 


\section{References and Notes.}

[1] A. Butler, Coord. Chem. Rev. 187 (1999) 17-35.

[2] J. Littlechild, Curr. Opin. Chem. Biol. 3 (1999) 28-34.

[3] J. Littlechild, E. Garcia-Rodrguez, A. Dalby, M. Isupov, J. Mol. Recognit. 15 (2002) 291296.

[4] A. G. J. Ligtenbarg, R. Hage, B. L. Feringa, Coord. Chem. Rev. 237 (2003) 89-101.

[5] W. Plass, Pure Appl. Chem. 81 (2009) 1229-1239.

[6] H. Vilter, K.-W. Glombitza, Bot. Mar. XXVI (1983) 341-344.

[7] M. Bhattacharjee, Polyhedron 11 (1992) 2817-2818.

[8] V. Conte, F. Di Furia, S. Moro, Tetrahedron Lett. 35 (1994) 7429-7432.

[9] C. U. Dinesh, R. Kumar, B. Pandey, P. Kumar, J. Chem. Soc., Chem. Commun. (1995) 611-612.

[10] H. B. ten Brink, A. Tuynman, H. L. Dekker, W. Hemrika, Y. Izumi, T. Oshiro, H. E. Schoemaker, R. Wever, Inorg. Chem. 37 (1998) 6780-6784.

[11] U. Bora, G. Bose, M. K. Chaudhuri, S. S. Dhar, R. Gopinath, A. T. Khan, B. K. Patel, Org. Lett. 2 (2000) 247-249.

[12] G. Rothenberg, J. H. Clark, Org. Process Res. Dev. 4 (2000) 270-274.

[13] J. S. Martinez, G. L. Carroll, R. A. Tschirret- Guth, G. Altenhoff, R. D. Little, A. Butler, J. Am. Chem. Soc. 123 (2001) 3289-3294.

[14] M. R. Maurya, H. Saklani, S. Agarwal, Catal. Commun. 5 (2004) 563-568.

[15] M. Greb, J. Hartung, F. Köhler, K. Ŝpehar R. Kluge, R. Csuk, Eur. J. Org. Chem. (2004) $3799-3812$.

[16] A. T. Khan, P. Goswami, L. H. Choudhury, Tetrahedron Lett. 47 (2006) 2751-2754. 
[17] T. Moriuchi, M. Yamaguchi, K. Kikushima, T. Hirao, Tetrahedron Lett. 48 (2007) 26672670.

[18] B. Sels, D. D. Vos, M. Buntinx, F. Pierard, A. Kirsch-De Mesmaeker, P. Jacobs, Nature 400 (1999) 855-857.

[19] V. Conte, F. Di. Furia, S. Moro, Tetrahedron Lett. 37 (1996) 8609-8612.

[20] G. Zhang, R. Liu, Q. Xu, L. Ma, X. Liang, Adv. Synth. Catal. 348 (2006) 862-866.

[21] A. Podgoršek, M. Eissen, J. Fleckenstein, S. Stavber, M. Zupan, J. Iskra, Green Chem. 11 (2009) 120-126.

[22] R. Newmann, I. Assael, J. Chem. Soc., Chem. Commun. (1988) 1285-1287.

[23] L. Menini, L. A. Parreira, E. V. Gusevskaya, Tetrahedron Lett. 48 (2007) 6401-6404.

[24] L. Yang, Z. Lu, S. S. Stahl, Chem. Commun. (2009) 6460-6462.

[25] K. Kikushima, T. Moriuchi, T. Hirao, Chem. Asian J. 4 (2009) 1213-1216.

[26] K. Kikushima, T. Moriuchi, T. Hirao, Tetrahedron Lett. 51 (2010) 340-342

[27] K. Kikushima, T. Moriuchi, T. Hirao, Tetrahedron 66 (2010) 6906-6911. 


\section{Scheme Captions}

Scheme 1. Gram-scale chlorination of propiophenone.

Scheme 2. Catalytic chlorination reaction of 2-iodo-1-phenylpropan-1-one. 


\section{Table 1}

Catalytic chlorination of propiophenone by using vanadium catalyst $/ \mathrm{Bu}_{4} \mathrm{NI} / \mathrm{AlCl}_{3} / \mathrm{O}_{2}$ system.

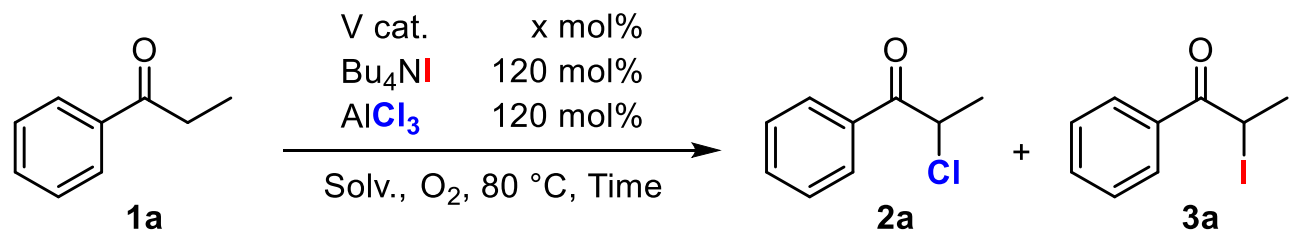

\begin{tabular}{|c|c|c|c|c|c|c|}
\hline \multirow{2}{*}{ Entry } & \multirow{2}{*}{ V cat. } & \multirow{2}{*}{$\begin{array}{c}\text { V cat. } \\
\text { x (mol\%) }\end{array}$} & \multirow{2}{*}{ Solv. } & \multirow{2}{*}{ Time (h) } & \multicolumn{2}{|c|}{ NMR yield $(\%)$} \\
\hline & & & & & $2 a$ & $3 a$ \\
\hline 1 & $\mathrm{NH}_{4} \mathrm{VO}_{3}$ & 10 & $\mathrm{MeCN}$ & 24 & 60 & 0 \\
\hline 2 & - & - & $\mathrm{MeCN}$ & 24 & 0 & 0 \\
\hline $3^{a}$ & $\mathrm{NH}_{4} \mathrm{VO}_{3}$ & 10 & $\mathrm{MeCN}$ & 24 & 7 & 0 \\
\hline 4 & $\mathrm{NH}_{4} \mathrm{VO}_{3}$ & 10 & $\mathrm{DME}^{b}$ & 24 & 31 & 0 \\
\hline 5 & $\mathrm{NH}_{4} \mathrm{VO}_{3}$ & 10 & $\mathrm{CPME}^{\mathrm{C}}$ & 24 & 36 & 0 \\
\hline $6^{d}$ & $\mathrm{NH}_{4} \mathrm{VO}_{3}$ & 10 & ether & 24 & 0 & 0 \\
\hline $7^{e}$ & $\mathrm{NH}_{4} \mathrm{VO}_{3}$ & 10 & $\mathrm{MeCN}$ & 24 & 64 & 0 \\
\hline 8 & $\mathrm{NH}_{4} \mathrm{VO}_{3}$ & 20 & $\mathrm{MeCN}$ & 24 & 77 & 0 \\
\hline 9 & $\mathrm{VO}\left(\mathrm{O}^{\prime} \mathrm{Pr}\right)_{3}$ & 20 & $\mathrm{MeCN}$ & 24 & 90 & 3 \\
\hline 10 & $\mathrm{VO}(\mathrm{acac})_{2}$ & 20 & $\mathrm{MeCN}$ & 24 & 69 & 9 \\
\hline 11 & $\mathrm{VOCl}_{3}$ & 20 & $\mathrm{MeCN}$ & 24 & 70 & 0 \\
\hline 12 & $\mathrm{NH}_{4} \mathrm{VO}_{3}$ & 20 & $\mathrm{MeCN}$ & 36 & 98 & 0 \\
\hline
\end{tabular}

${ }^{a} \mathrm{Ar}$ atmosphere

${ }^{b}$ 1,2-Dimethoxyethane

${ }^{c}$ Cyclopentylmethylether

${ }^{d}$ Room temperature

${ }^{e} 200 \mathrm{~mol} \%$ of $\mathrm{Bu}_{4} \mathrm{NI}$ and $\mathrm{AlCl}_{3}$ were used. 


\section{Table 2}

The effect of a halide source and aluminium halide in catalytic halogenation of propiophenone by using cat. $\mathrm{NH}_{4} \mathrm{VO}_{3}$.

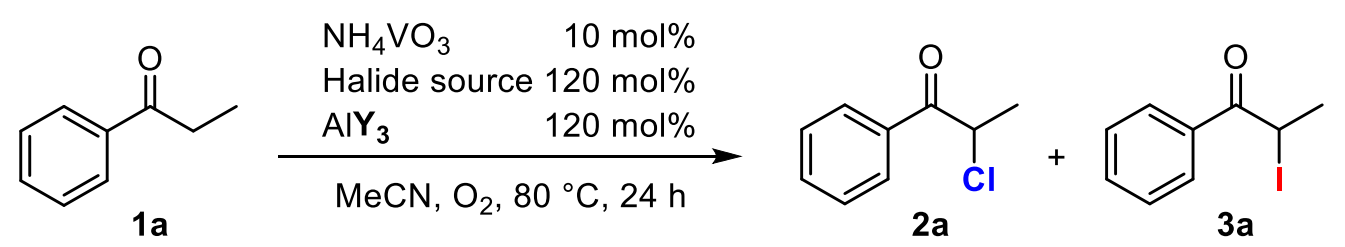

\begin{tabular}{ccccc}
\hline \multirow{2}{*}{ Entry } & Halide source & $\mathrm{AlY}_{3}$ & \multicolumn{2}{c}{ NMR yield (\%) } \\
\cline { 4 - 5 } & $\mathrm{Bu}{ }_{4} \mathrm{NI}$ & $\mathrm{AlCl}_{3}$ & 60 & 0 \\
\hline 1 & $\mathrm{KI}$ & $\mathrm{AlCl}_{3}$ & 7 & 9 \\
2 & $\mathrm{Bu}_{4} \mathrm{NCl}$ & $\mathrm{All}_{3}$ & 58 & 16 \\
3 & $\mathrm{Bu}_{4} \mathrm{NCl}$ & $\mathrm{AlCl}_{3}$ & 5 & 0 \\
4 & $\mathrm{Bu}_{4} \mathrm{NI}$ & $\mathrm{All}_{3}$ & 0 & $33^{a}$ \\
5 & $\mathrm{Bu}_{4} \mathrm{NI}$ & $\mathrm{All}_{3}$ & 0 & $49^{a}$ \\
$6^{b}$ & & & & \\
\hline
\end{tabular}

${ }^{a}$ Benzoic acid was obtained as a by-product.

${ }^{b}$ Reaction time: $48 \mathrm{~h}$ 
Table 3

Catalytic chlorination of ketones by using cat. $\mathrm{NH}_{4} \mathrm{VO}_{3} / \mathrm{Bu}_{4} \mathrm{NI} / \mathrm{AlCl}_{3} / \mathrm{O}_{2}$ system.

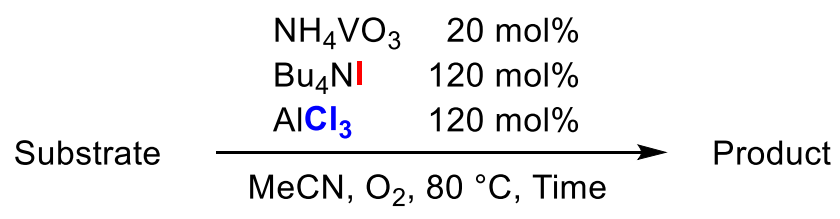

Entry Substrate




\section{Table 4}

Catalytic chlorination of ketones by using cat. $\mathrm{VO}\left(\mathrm{O}^{i} \mathrm{Pr}\right)_{3} / \mathrm{Bu}_{4} \mathrm{NI} / \mathrm{AlCl}_{3} / \mathrm{O}_{2}$ system.

\begin{tabular}{|c|c|c|}
\hline & $\mathrm{VO}\left(\mathrm{O}^{i}\right.$ & $25 \mathrm{~mol} \%$ \\
\hline & $\mathrm{Bu}_{4} \mathrm{NI}$ & $120 \mathrm{~mol} \%$ \\
\hline & $\mathrm{AlCl}_{3}$ & $120 \mathrm{~mol} \%$ \\
\hline
\end{tabular}

\begin{tabular}{|c|c|c|c|}
\hline Entry & Substrate & Time (h) & $\begin{array}{c}\text { Products } \\
\text { NMR yield (\%) }\end{array}$ \\
\hline
\end{tabular}

1<smiles>COc1ccc(C(C)=O)cc1</smiles>

$1 \mathrm{~b}$<smiles>CC(=O)c1ccc(Cl)cc1</smiles>

25

3<smiles>CC(=O)c1ccccc1</smiles>

24<smiles>COc1ccc(C(=O)CCl)cc1</smiles>

2b

44<smiles>O=C(CCl)c1ccc(Cl)cc1</smiles>

66<smiles>O=C(CCl)c1ccccc1</smiles>

$2 e$

84

24<smiles>COc1ccc(C(=O)C(Cl)Cl)cc1</smiles>

$2 b b$

13<smiles>CC(C)(C)c1ccc(C(=O)C(Cl)Cl)cc1</smiles>

13<smiles>O=C(CI)c1ccc(Cl)cc1</smiles>

4<smiles>O=C(c1ccccc1)C(Cl)Cl</smiles>

2 ee<smiles>O=C(CI)c1ccccc1</smiles>

12<smiles>COc1ccc(C(=O)CI)cc1</smiles>

1 


\section{Table 5}

Catalytic chlorination of alkenes by using cat. $\mathrm{VO}\left(\mathrm{O}^{i} \mathrm{Pr}\right)_{3} / \mathrm{Bu}_{4} \mathrm{NI} / \mathrm{AlCl}_{3} / \mathrm{O}_{2}$ system.

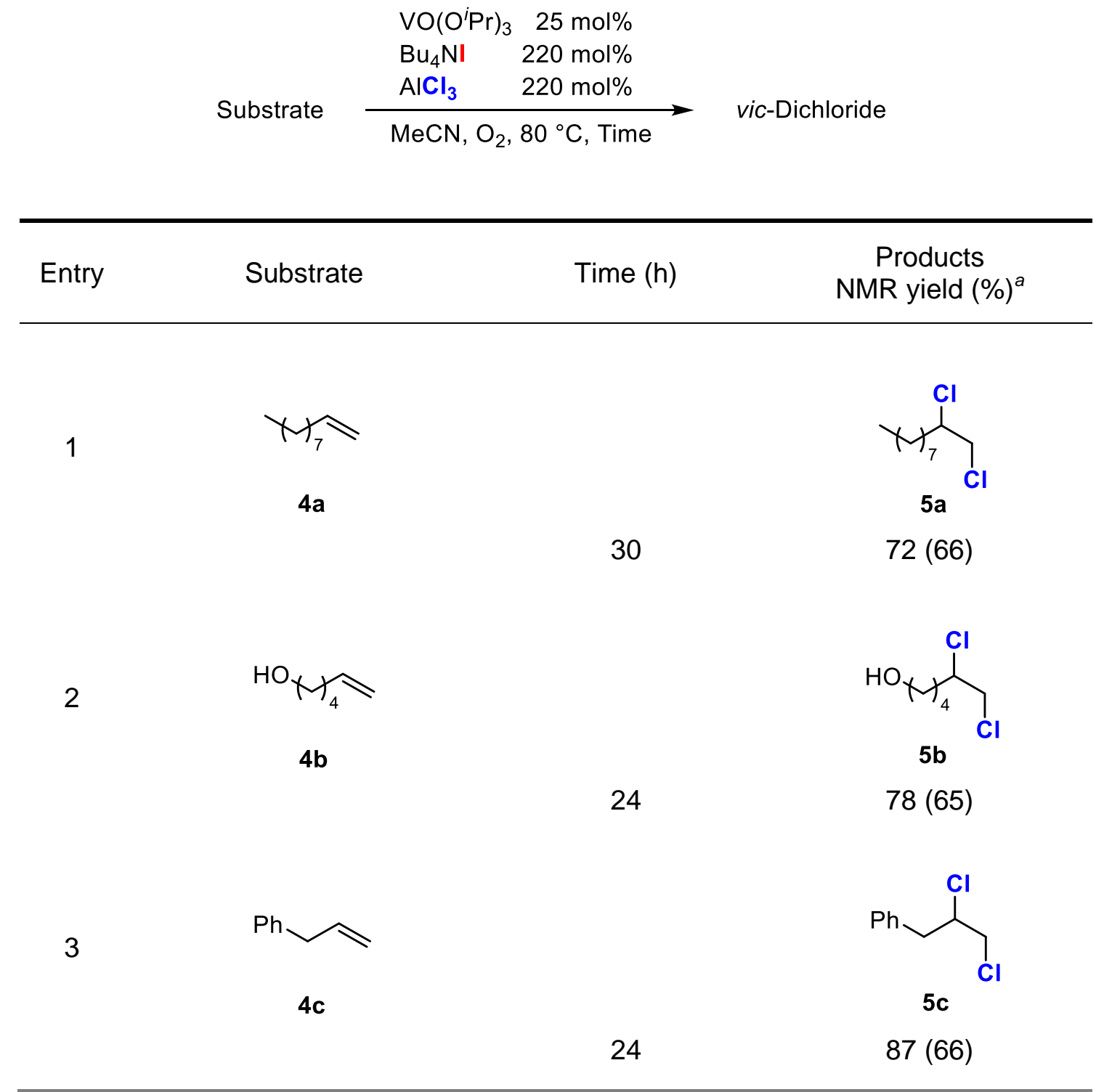

${ }^{a}$ Numbers in parentheses show isolated yields. 


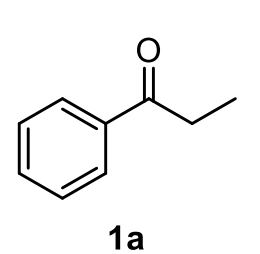

$1.33 \mathrm{~mL}(10 \mathrm{mmol})$

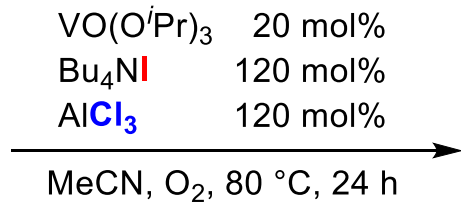

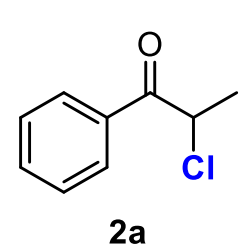

$1.32 \mathrm{~g}(7.8 \mathrm{mmol})$

$78 \%$

Scheme 1. 


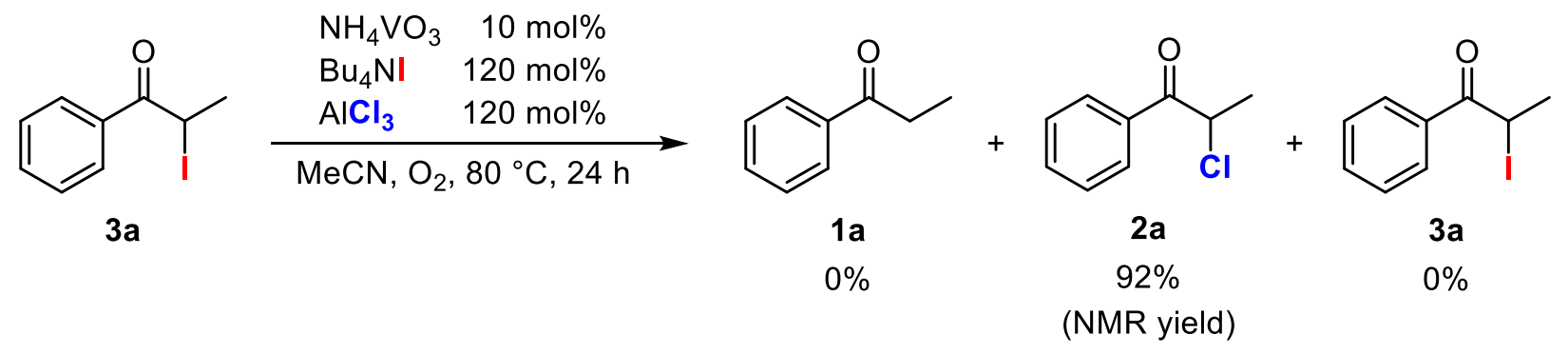

Scheme 2. 
Pictogram

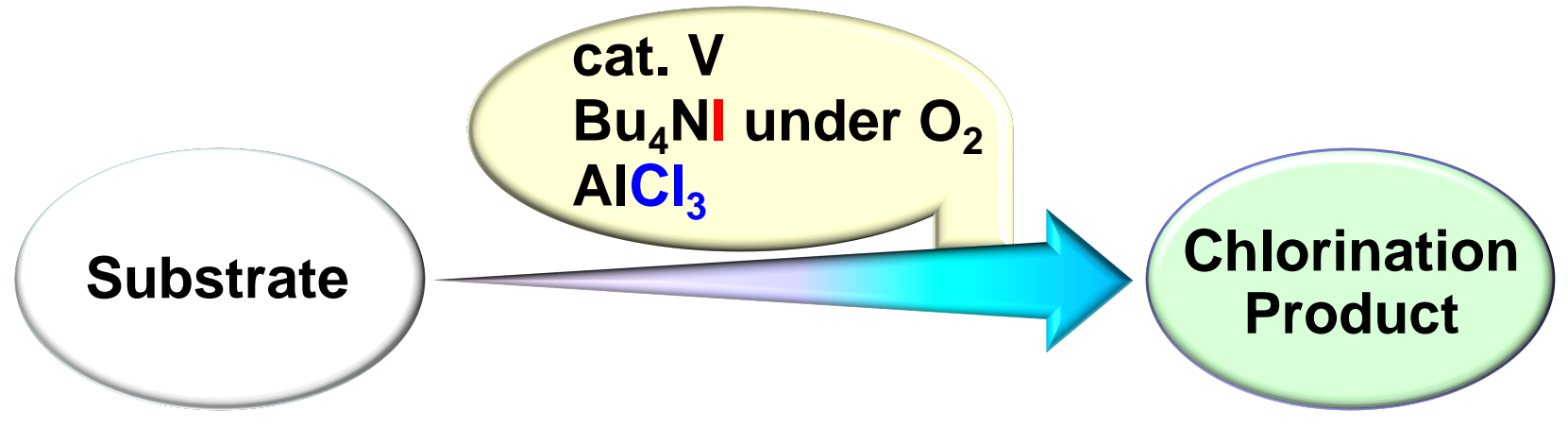

